\title{
LIPID PROFILE AND CHRONIC RENAL FAILURE
}

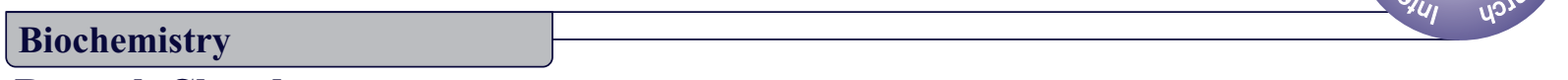

Ramesh Chandra Assistant professor, Biochemistry, Amaltas institute of medical sciences. *Corresponding Thanna* Author

Dr. BK Agarwal

Professor of Biochemistry \& P.G. Director, Index medical college Hospital and Research Centre, Indore (M.P)

\section{Dr. Rakesh Romday}

Professor Of Medicine, Amaltas Institute Of Medical Sciences, Dewas, M.P.

\section{ABSTRACT}

Introduction: Chronic kidney disease (CKD), diabetes and cardiovascular disease are harmful chronic diseases that commonly occur together. Methods : present study was done in Amaltas medical college and index medical college, indore, m.p.. We have assessed serum creatinine urea and lipid profile level in Chronic renal failure patients.

Results: we have found a highly significant change in serum Urea, uric acid and lipid profile in Subjects in comparisons to control

Conclusion: Chronic renal failure is positively associated with deranged lipid profile and a great risk of cardiac diseases.

\section{KEYWORDS}

CRF, CVD, lipid profile.

\section{INTRODUCTION:}

Chronic kidney disease (CKD) is a worldwide major public health problem, with increasing incidence, prevalence, high costs and poor outcomes. 1 More than 50 million people world-wide have CKD, and more than one million of them are receiving kidney replacement therapy. Additionally, because of the age-related decline in GFR that may largely be a attributable to hypertension, atherosclerosis, or heart failure, the incidence of CKD increases with age. (1)

There clearly is a direct correlation of increasing levels of total and LDL cholesterol with increasing risk for coronary artery disease (CAD) and coronary mortality $(2,3)$. Treatment with LLD has shown clear benefit in primary prevention in individuals with hypercholesterolemia (4-8). we believe that there is a strong argument to abandon a threshold-based algorithm for treating hyperlipidemia. Rather, it may be advisable to treat those with high risk for atherosclerotic cardiac events regardless of initial LDL level and to treat with a potent dosage of a statin alone or in combination with a second-line drug to achieve a marked. (9)

\section{MATERIALAND METHODS :}

Unique ID number was given to each participant of the study and same ID was given on sample container. After obtaining informed consent from all patients and healthy control, $5 \mathrm{ml}$ of venous blood was collected in a sterile plain bulb under all aseptic precautions. Blood was drawn from anticubital vein in plain vial. After samples collection, samples were centrifuged in REMI centrifuge at 3000 RPM for a period of 15 minutes at central laboratory of Amaltas Hospital. Serum was separated after centrifugation. Serum was kept frozen at $20 * \mathrm{C}$ (for IL-6) until assayed. While analyzed for the following parameters:- $\quad$ urea, lipid profile. Machine used Chem-7 semi automated and EM-360 fully automated.

\section{Statically Analysis:}

Calculated mean Sd and student t-test, Correlations with the help of Ms- Excel 2010.

\section{RESULTS:}

The results demonstrated elevation in plasma value of urea, lipid profile in patients with CRF.

Table-1 Urea Level In Subjects And Control.

\begin{tabular}{|l|l|l|l|}
\hline & Mean \pm SD & t-test & p-value \\
\cline { 1 - 2 } Subjects & $157.60 \pm 55.02$ & 31.4185 & $0.0001 \mathrm{~S}$ \\
\cline { 1 - 2 } Control & $35.17 \pm 3.12$ & & \\
\hline
\end{tabular}

Table-2 Lipid Profile Level

\begin{tabular}{|l|l|l|l|}
\hline & Subject $($ Mean \pm SD) & Control $($ Mean \pm SD) & p-value \\
\hline TC & $331.73 \pm 71.80$ & $110.17 \pm 10.12$ & $0.0001 \mathrm{~S}$ \\
\hline TG & $246.28 \pm 71.20$ & $130.48 \pm 10.18$ & $0.0001 \mathrm{~S}$ \\
\hline
\end{tabular}

\begin{tabular}{|l|l|l|l|}
\hline HDL & $29.82 \pm 27.3$ & $48.12 \pm 10.19$ & $0.0001 \mathrm{~S}$ \\
\hline LDL & $151.2 \pm 65.60$ & $70.88 \pm 5.22$ & $0.0001 \mathrm{~S}$ \\
\hline VLDL & $49.25 \pm 14.2$ & $26.9 \pm 2.06$ & $0.0001 \mathrm{~S}$ \\
\hline
\end{tabular}

\section{DISCUSSION:}

Chronic kidney disease is a major public health problem throughout the world. (10) The risk of CVD morbidity and mortality is high in all stages of CKD. However, it becomes more evident upon the initiation of dialysis treatment. The atherosclerotic cardiovascular disease is the most frequent complication in patients undergoing chronic hemodialysis treatment. A.(11)

CRF results in profound dysregulation of several key enzymes and receptors involved in the metabolism of lipoproteins, particularly those of HDL and triglyceriderich lipoproteins. Downregulation of LCAT, apoA-1, and hepatic lipase together with upregulation of cholesterol ester transfer protein (CETP) are largely responsible for the reduction in HDL cholesterol and elevation of HDL triglyceride in CRF patients with and without hemodialysis. (12)

Down regulation of skeletal muscle and adipose tissue LPL, hepatic lipase, and the VLDL receptor and of hepatic LDL Receptor-Related Protein (LRP) is collectively responsible for hypertriglyceridemia, impaired clearance, and elevated plasma levels of VLDL, IDL, and chylomicron remnants despite downregulation of hepatic triglyceride synthetic capacity (DGAT).(13. ) In our study we found elevated levels of VLDL cholesterol and decreased levels of HDL cholesterol in CRF patients as compared to controls. The difference attained was statistically significant. Amin et al. reported the same findings.

\section{CONCLUSION:}

These lipid abnormalities enhance the risk of developing cardiovascular disease in these patients. A strict monitoring of lipid profile can reduce the morbidity and mortality rate and will also improve the quality of life of CRF patients.

\section{REFERENCES:}

Gravis JW. Diagnosis and management of chronic kidney disease.Mayo Clin. Proc. 2008; 83(9):1064-1069.

2.Schoolwerth AC, Engelgau MM, Hostetter TH, Rufo KH,Chianchiano D and McClellan WM. Chronic kidney disease: a public health problem that needs a public health action plan. Am. J. Kidney Dis. 2006; 51(4 Supp2):S30-37.

Dreuke TB. Arterial intima and media calcifi cation: distinct entities with diff eren pathogenesis or all the same? Clin. J. Am. Soc. Nephrol. 2008;3(6):1583-1584.

Coglar K, Yilmaz MI, Saglam M, Cakir E, Acikel C, Eyileten T. Short-term treatmen with sevelamer increases serum fetuin-a concentration and improves endothelia dysfunction in chronic kidney disease stage 4 patients. Clin. J. Am. Soc. Nephrol.; 3(1):61-68.

5. Amann K. Media calcifi cation and intima calcifi cation are distinct entities in chronic kidney disease. Clin. J. Am. Soc. Nephrol. 2008;3(6):1599-1605.

Toussaint ND, Lau KK, Strauss BJ, Polkinghorne KR and Kerr PG. Association between vascular calcifi cation, arterial stiff ness and bone mineral density in chronic kidney disease

Ix JH, Wassel CL, Kanaya AM, Vi inghoff E, Johnson KC., Koster A.et al. Fetuin-A and 
incident diabetes mellitus in older persons.JAMA 2008; 300(2):182-188.

8. Reynolds JL, Skepper JN, McNair R, Kasama T, Gupta K, Weissberg PL et al. Multifunctional roles for serum protein fetuin-a in inhibition of human vascular smooth Multifunctional roles for serum protein fetuin-a in inhibition of human
muscle cell calcifi cation. J. Am. Soc. Nephrol. 2005; 16(10):2920-2930.

9. Foley RN, Parfrey PS, Sarnak MJ: Clinical epidemiology of cardiovascular disease in chronic renal disease. Am JKidneyDis 32: S112-S119, 1998

10. Pekkanen J, Linn S, Heiss G, Suchindran CM, Leon A, Rifkind BM, Tyroler HA: Tenyear mortality from cardiovascular disease in relation to cholesterol level among men with and without preexisting cardiovascular disease. NEngl.JMed 322: 1700-1707, 1990

11. MRC/BHF Heart Protection Study of cholesterol lowering with simvastatin in 20,536 high-risk individuals: a randomized placebo-controlled trial. Lancet 360: 7-22, 2002

2. Saland JM, Ginsberg HN. Lipoprotein metabolism in chronic renal insufficiency. Pediatr Nephrol 2007; 22:1095-1112

13. Lippi G, Guidi G. Lipoprotein(a): from ancestral benefit to modern pathogen?, Q J Med 2000;93:75-84. 20 . 